\title{
PENGETAHUAN EKOLOGI MASYARAKAT LOKAL SEBAGAI INDIKATOR PENILAIAN POTENSI LAMUN (SEAGRASS) DI TANJUNG LUAR LOMBOK TIMUR
}

\author{
Abdul Syukur \\ (Dosen pada Program Studi Pendidikan Biologi FKIP Universitas Mataram)
}

\begin{abstract}
Abstraks
Lamun adalah jenis tumbuhan tingkat tinggi yang telah dikenal cukup lama oleh masyarakat di wilayah pesisir. Tujuan dari artikel ini adalah memformulasikan secara konseptual bentuk pengetahuan ekologi masyarakat lokal sebagai instrumen penilaian perubahan kondisi lamun. Teknik sampling yang digunakan adalah quota sampling dengan kriteria responden umurnya $\geq 40$ tahun dan jenis pekerjaan utama sebagai nelayan. Selain itu untuk mendapatkan informasi yang lebih lengkap dan mendalam digunakan teknik snowball sampling. Analisis data di lakukan secara diskriftif. Hasil penelitian ini menunjukkan bahwa pengetahuan ekologi masyarakat lokal cukup komprehensip. tentang lamun. Klasifikasi jenis lamun oleh masyarakat lokal menjadi 4 jenis yaitu lamun kaken (Enhalus acoroides), lamun ranten (alga), lamun hijau dan lamun pupak (rumput). Distribusi tiap jenis lamun dan fungsi lamun terhadap ikan dan biota laut dalam perspektif masyarakat tidak berbeda dengan yang dijelaskan oleh sumber-sumber secara ilmiah. Kesimpulan dari penelitian ini adalah pengetahuan ekologi masyarakat lokal dapat menjadi instrumen pengelolaan lamun, terutama dalam mendeteksi perubahan kondisi lamun akibat gangguan baik dari alam maupun antropogenik.
\end{abstract}

Kata kunci: Pengetahuan Ekologi dan Potensi Lamun

\begin{abstract}
Seagrass is a kind of higher plants that have been known for a long time by the people in the coastal areas. The purpose of this article is to formulate a conceptual form of local ecological knowledge as an instrument of change in the condition assessment of seagrass. The sampling technique used was quota sampling criteria respondents aged $\geq 40$ years and the main job as a fisherman. Moreover, to obtain more detailed information and in-depth use snowball sampling technique. Data analysis was done in descriptive. The results of this study indicate that local ecological knowledge quite comprehensively . on seagrass . Classification of seagrass by local communities into 4 types: seagrass Kaken (Enhalus acoroides ), seagrass Ranten ( algae ), seagrass and seagrass pupak green ( grass ). Distribution and function of each type of seagrass seagrass on fish and marine life in the perspective of society not dissimilar to that described by scientific sources. The conclusion of this study is local ecological knowledge can be instrumental seagrass management, especially in the detection of changes in the condition of seagrass due to interference from both natural and anthropogenic .
\end{abstract}

Key Words: Ecology Knowledge and Potential Seagrass 


\section{PENDAHULUAN}

L amun (seagrass) merupakan pondasi spesies pada lingkungan laut (Waycott et al 2009), hal ini berkaitan dengan fungsi lamun yang sangat penting untuk spesies lain untuk dapat survive. Misalnya ikan dapat survive karena lamun menyedikan tempat bagi ikan untuk pemijahan (spawning ground), tempat asuhan (nursery ground) dan tempat mencari makan (DKP 2008). Selain itu lamun di lingkungan laut menyediakan jasa ekosistem yang cukup substansial seperti untuk makanan dugongs, turtles dan beberapa ikan herbivora serta sea urchins (Björk et al 2008). Selanjutnya dijelaskan bahwa akar dan dan rhizoma lamun berperan sebagai stabilisasi sedimen dan mencegah erosi melalui daun serta menyaring suspensi sedimen serta nutruen dari kolom air. Disamping itu keberadaan lamun dari aspek ekologi memiliki keterkaitan secara fungsional dan struktural dengan habitat lain seperti terumbu karang, mangrove, salt marshes dan oyster reefs. Dalam hal ini lamun merupakan satu kesatuan sistem dari sistem ekologi pesisir, sehingga dalam pengelolaanya membutuhkan pemahaman aspek ekologi lamun secara khusus (Turner and Anne-Maree Schwarz 2006).

Padang lamun memiliki fungsi yang cukup vital dan sebagai salah satu ekosistem yang memiliki produktivitas tinggi, regulasi gas $\mathrm{CO}_{2}$ secara signifikan dan meningkatkan keanekaragaman hayati (Larkum et al 2006). Meskipun posisi cukup penting, ekosistem padang lamun saat ini telah mengalami penurun secara dramatik pada banyak tempat di wilayah pesisir, secara global kerusakan lamun diestimasi sebnesar 2-7\%/tahun (Orth at al 2006; Duarte and Gattuso 2008). Sumber kerusakan lamun yang telah teridentifikasi adalah dari aktivitas manusia seperti penebangan hutan (deforestation), penebangan pohon mangrove dan gangguan vegetasi lain di wilayah pesisir, sehingga dapat meningkatkan jumlah sedimen yang terbawa oleh aliran sungai dan sampai ke padang lamun. Peningkatan jumlah sedimen berakibat pada menurunya kejernihan air laut dan mengurangi cahaya yang sampai ke lamun, sehingga dapat menghambat pertumbuhan dan perkembangan lamun. Di dunia saat ini hilangan lamun merupakan ancaman utama pada ekosistem di wilayah pesisir (Short and Wyllei-Echeverria 1996; Short et al 2007) dan masih kurang mendapat perhatian dibandingkan ekosistem lain seperti terumbu karang (Duarte et al 2008).

Lamun pada dasarnya telah lama terpublikasi secara internasional sebagai spesies tumbuhan berbungan dan ekosistem penting di lingkungan laut (IUCN 2008), hal ini dapat dilihat dari publikasi lamun yang pertama kali diperkenalkan secara formal oleh den Hartog (1970) yaitu merupakan jenis tumbuhan berbunga yang hidup di lingkungan laut, selanjutnya publikasi lamun sebagai ekosistem dalam perspektif ilmiah (scientific perspective) di terbitkan oleh McRoy and Helfferich (1977), dalam bentuk buku sebagai pedoman biologi lamun diterbitkan oleh Phillips and McRoy (1980), biologi lamun sebagai reperensi khusus di Australia diterbitkan oleh Larkum, McComb and Shepherd (1989), ekologi lamun diterbitkan oleh Hemminga and Duarte (2000), Atlas lamun diterbitkan oleh Green and Short (2003) serta biologi, ekologi dan konservasi lamun secara komprehensip diterbitkan oleh Larkum, Orth and Duarte (2006).

Lamun yang telah dikenal dari publikasi ilmiah, terutama dari aspek ekologi dan ekonomi serta jumlah areal lamun yang hilang serta gangguan yang cukup serius dari aktivitas antropogenik, menjadi sumber kesadaran secara internasional untuk melakukan perlindungan. Konservasi lamun atau perlindungan lamun yang telah terpublikasi secara internasional serta berhasil dalam meningkatkan biomassa ikan 
adalah konservasi dan pengelolaan lamun di Teluk Chesapeake USA yang menggunkan kriteria kualitas air sebagai instrumen, konservasi lamun pada areal Taman Nasional Great Barrier Reef Australia dilakukan dengan perluasan areal perlindungan laut, konservasi lamun di Filipina dan Karibbia yaitu dengan cara menintegrasikannya dalam program pengelolaan Marine Protected Area (MPA) dan diperkuat oleh undang-undang, konservasi lamun di Mediterranean dilakukan melalui restorasi yaitu dengan cara rehabilitasi habitat (Larkum et al. 2006). Konservasi dan pengelolaan lamun di perairan Indonesia telah terintegrasi dalam sistem pengelolaan kawasan konservasi Taman Nasional Laut, Konservasi Laut Daerah dan Kawasan Konservasi Taman Wisata Alam Laut dan Suaka Perikanan (DKP 2008).

Publikasi lamun khususnya di Pulau Lombok masih sangat terbatas yaitu hanya lamun pada daerah-daerah wisata seperti di Kute dan Gerupuk (Tomascik et al 1997). Publikasi lain adalah keragaman jenis lamun dan kondisinya serta keanekaraman jenis ikan yang berasosiasi dengan lamun di perairan pesisir Tanjung Luar Lombok Timur (Syukur et al 2011 dan Syukur et al 2012). Informasi yang terbatas, menjadi kendala dalam perlindungan dan pengelolaan lamun, khususnya di Pulau Lombok. Publikasi lamun yang sangat kurang dibandingkan dengan ekosistem lain seperti terumbu karang dan mangrove telah berdampak pada belum memadai usaha perlindungan lamun, meskipun memiliki nilai ekologi dan ekonomi yang tidak jauh berbeda (Cullen dan Unsworth 2010).

Saat ini usaha dan pendekatan pengelolaan serta perlindungan sumberdaya alam di wilyah pesisir telah banyak dilakukan, termasuk dalam perlindungan ekosistem padang lamun. Diantara pendekatan pengelolaan yang dikenal adalah pendekatan pengelolaan berbasis ekologi, ekonomi dan masyarakat atau yang sering disebut sebagai pendekatan top down dan botom up atau gabungan keduanya. Salah satu pendekatan yang masih sangat kurang dieksplorasi sebagai dasar pengelolaan atau instrumen dalam pengelolaan adalah nilai pengetahuan ekologi masyarakat lokal.

Pengetahuan ekologi masyarakat lokal sangat penting untuk pengelolaan sumberdaya alam dan dapat mendorong perubahan paradigma pengelolaan yang berpusat pada pengeloaan dengan pendekatan adaptif managemen (Hughes et al 2005), argumentasi ini didukung oleh pakta bahwa keberlanjutan dalam pengelolaan sumberdaya alam, ketika umpan balik (feedbacks) antara masyarakat dan ekosistem adalah bentuk adaptif dari kebijakan pengelolaan. Sistem tradisional pada dasarnya merupakan kerangka kerja pengelolaan pada tingkat lokal yang berstandar pada pengetahuan dan keahlian (expertise) yang dapat berdampak pada pendekatan adaptif menejemen (Dietz et al 2003).

Pengelolaan padang lamun di wilayah pesisir Tanjung Luar belum ada secara operasional dalam manejemen pengelolaan, mulai dari menejemen pemerintah di tingkat desa sampai kabupaten dan bahkan secara sektoral dari Dinas Perikanan dan Kelautan Lombok Timur. Oleh karena itu bagian utama yang menjadi fokus dalam studi ini adalah pengetahuan ekologi masyarakat lokal tentang lamun yang berkaitan dengan struktur pengetahuan masyarakat lokal dan keterkaitan lamun dengan ekosistem lain di wilayah pesisir Tanjung Luar Lombok Timur. Pengetahuan ekologi masyarakat lokal di lokasi studi dapat mmenjadi instrumen dalam desain pengelolaan lamun dan sumberdaya ekosistem lain untuk keberlanjutan sumberdaya ikan. Dalam hal ini pengetahuan ekologi masyarakat memiliki posisi yang cukup esensial dari berbagai pendekatan pengelolaan yang telah dilaksanakan untuk mencegah degradasi nilai-nili jasa dan barang yang dihasilkan dari ekosistem utama di wilayah pesisir seperti 
ekosistem padang lamun, terumbu karang dan mangrove.

\section{Bahan dan Metode}

Penelitian ini dilakukan pada bulan Oktober sampai November 2012, populasi penelitian adalah masyarakat di Desa Tanjung Luar, Desa Ketapang Raya, Desa Maringkik dan Desa Jerowaru. teknik sampling yang digunakan adalah quota sampling. Informasi yang dibutuhkan dari tiap responden sebagai sampel penelitian adalah tentang struktur pengetahauan ekologi masyarakat lokal yaitu: jenis dan distribusi spesies lamun, biota laut yang selalu membutuhkan lamun untuk dapat survive, perubahan kondisi lamun dan manfaat lamun bagi masyarakat lokal secara ekonomi.

Sampel dalam penelitian dipilih dengan kriteria yaitu umur responden $\geq 40$ tahun dan jenis pekerjaan utama responden adalah nelayan. Selain itu untuk mendapatkan informasi yang lebih lengkap dan mendalam digunakan teknik snowball sampling. Teknik ini digunakan untuk mendapakan responden yang memiliki pengetahuan paling luas tentang lamun di lokasi studi. Selanjutnya tiap responden di wawancara secara langsung (face-to-face interviews) dengan interval waktu berkisar antara $10-20$ menit. Teknik sampling ini bertujuan untuk mendapatkan standar dan kedalaman informasi tentang struktur pengetahuan ekologi dari setiap sampel yang menjadi responden (Aswani and Lauer 2006; Lauer and Aswani 2008; 2009). Selanjutnya selama proses wawancara pertanyaan dan fokus diskusi ditekankan pada aspek ekologi lamun yang meliputi keragaman jenis lamun dan batas distribusi tiap jenis lamun, perubahan-perubahan kondisi lamun yang dirasakan dan dapat dinilai secara kualitaif dan kuantitatif dan sumber-sumber ancaman kerusakan lamun yang cukup potensial pada beberapa tahun sebelumnya saat ini dan massa yang akan datang.
Data yang diperoleh pertama dilakukan tabulasi yaitu untuk mengelompokkan data sesuai dengan sifat data. Data yang berupa nama jenis lamun dan biota laut selanjutnya dikonfirmasi sesuai dengan nama ilmiah (scientific). Kedua data yang berkaitan dengan distribusi tiap jenis lamun di validasi dengan observasi langsung ke lokasi padang lamun pada saat air surut, demikian juga halnya dengan data yang berkaitan dengan jenis biota laut yang dimanfaatkan oleh masyarakat atau diambil dari lokasi padang lamun. Ketiga data yang berkaitan dengan perubahan kondisi lamun, konfirmasinya dilakukan berdasarkan pada prosentase persepsi responden yaitu perubahan lamun secara fisik yang berkaitan dengan kesuburan pertumbuhan lamun dan berkurangnya areal lamun, demikian juga halnya dengan manfaat serta keterkaitan lamun dengan ekosistem lain dikonfirmasi berdasarkan prosentase persepsi responden sebagai sampel penelitian.

Data lamun yang telah ditabulasi, selanjutnya dianalisis untuk mendapat gambaran secara konseptual tentang struktur pengetahuan ekologi masyarakat lokal tentang lamun di lokasi studi. Diskripsi secara konseptual tentang ruang lingkup struktur pengetahuan ekologi masyarakat selanjutnya dibandingakan dengan diskripsi lamun dari aspek yang sama dalam perspektif ekologi (Few 2009 dan Daerden et al 2005). Hasil analisis ini dapat memetakan posisi pengetahuan ekologi masyarakat lokal sebagai instrumen pengelolaaan padang lamun yang memiliki fungsi vital untuk menilai keberlanjutan sumberdaya alam pada ekosistem padang lamun.

\section{HASIL DAN PEMBAHASAN}

\section{Jenis dan Distribusi Lamun}

Lamun cukup dikenal oleh masyarakat di lokasi studi, hal ini diindikasikan oleh semua responden yang di wawancara 
mengenal lamun sebagai tumbuhan yang hidup pada lingkungan laut yang dangkal. Keragaman jenis lamun yang ada di wilayah studi sebenarnya berjumlah 9 spesies yaitu Enhalus acoroides, Halophila ovalis, Halophila minor, Halophila spinulosa, Cymodocea rotundata, Cymodocea serrulata, Halodulle pinifolia, Thalassia hemprichii dan Syringodium isotifolium (Syukur et al 2011). Jumlah jenis lamun berdasarkan persepsi masyarakat di lokasi studi sebanyak 4 jenis yaitu: (1) lamun kaken yaitu jenis lamun Enhalus acoroides, jenis lamun ini adalah jenis lamun yang paling dikenal oleh masyarakat karena buahnya yang dapat diambil sebagai sayur-sayuran, dan hal ini yang menjadi dasar pemberian namanya karena buahnya dapat dimakan (kaken), (2) lamun ranten yaitu jenis lamun yang tergolong pada genus Halophila, jenis lamun ini diberi nama demikian berdasarkan persepsi masyarakat karena bentuk dan tumbuh menjalar menyerupai ranten (algae) yang menjadi bahan komsumsi atau sayursayuran, (3) lamun hijau adalah jenis lamun yang tergolong dalam genus Cymodocea dan menurut persepsi masyarakat karena lamun ini selalu menampakkan warna hijau sepanjang tahun dan (4) lamun pupak, kelompok ini adalah jenis lamun Halodulle pinifolia dan Syringodium isotifolium, pemberian nama ini didasarkan pada bentuk morfologinya yang kecil dan tumbuh seperti rumput (pupak).

Masyarakat memiliki pengetahuan yang cukup memadai tentang distribusi tiap jenis lamun, hal sesuai dengan yang didiskripasikan oleh responden yaitu jenis lamun pupak (rumput) tumbuh dan berkembang pada pantai yang berpasir dan sedikit lumpur dan paling dekat dengan pinggir pantai. Jenis lamun hijau adalah jenis lamun yang tumbuh lebih tengah dari pantai dan umumnya lumpurnya lebih banyak dan jenis lamun ranten (alga) tumbuh bersama jenis lain di pinggr pantai dan pada saat air surut dapat dilihat terutama pada saat masyarakat mengambil alga (ranten) sebagai sumber makanan dan lamun kaken (makan) jenis lamun yang ditemukan pada areal yang lebih banyak lumpur dan banyak ditemukan bersama-sama dengan lamun hijau.

Diskripsi jumlah jenis dan distribusi tiap jenis lamun dapat menggambarkan bahwa masyarakat memiliki pengetahuan ekologi yang cukup memadai dalam mengenal sumberdaya alam seperti lamun yang ada di sekitar lingkungannya. Pemahaman masyarakat dalam memetakan potensi jenis dan distribusi lamun, dalam perspektif ekologi tentu sangat penting, karena hal ini dapat menjadi indikator dalam melakukan memonitoring status lamun, jika ada gangguan (distrubance) yang bersumnber dari aktivitas antropogenik dan alam seperti badai, gempa tektonik dan perubahan iklim global (climate change).

\section{Perspektif Masyarakat Lokal tentang Lamun}

.Masyarakat di lokasi studi tidak hanya mmengenal lamun sebagai tumbuhan di lingkungan laut, tetapi buah lamun dapat menjadi sumber sayur-sayuran. Selain kedua hal tersebut masyarakat memahami keberadaan lamun di lingkungan laut secara lebih luas yaitu tempat hidup banyak biota laut. Hasil identifikasi tentang manfaat lamun adalah habitat ikan dan beberapa biota lain seperti tripang, moluska dan see-urchin. Jenis ikan yang memiliki ketergantungan yang cukup besar pada lamun adalah ikan baronang (siganidae), karena ini makanannya daun lamun. Selain itu banyak jenis ikan lain yang ditemukan pada areal lamun dan bernilai ekonomi seperti ikan dari famili Monacantidae, Lutjanidae, Lethrinidae, Haemullidae dan Mugilidae.

Pemahaman masyarakat tentang keragaman jenis ikan dan biota laut lainnya yang ada pada lokasi padang lamun dapat menjadi indikator sebagai instrumen pengelolaaan yang bersumber dari pengetahuan ekologi masyarakat lokal. 
Selain keragaman jenis ikan indikator lain yang menunjukkan pemahaman masyarakat lokal tentang fungsi ekologi lamun adalah ikan yang masih ikan membutuhkan lamun sebagai tempat hidup. Indikator-indikator pengetahuan ekologi masyarakat lokal tentang fungsi lamun bagi biota laut cukup relevan sebagai instrumen perlindungan lamun atau konservasi lamun di lokasi studi.

Pengetahuan ekologi masyarakat lokal pada dasarnya adalah bentuk akumulasi pemahaman yang diperoleh secara langsung berinteraksi dengan sumberdaya yang ada pada padang lamun dan informasi yang diperoleh dari pendahulunya. Identifikasi tingkat pengetahuan ekologi masyarakat terhadap suatu sumberdaya alam seperti padang lamun dapat dinilai dari barang dan jasa (goods and services) yang diperoleh dari lokasi padang lamun (Ronnback dan TorreCastro 2004). Namun demikian dalam penetapan indikator yang bersumber dari masyarakat, selalu terdapat perbedaan persepsi yang dipengaruhi oleh tingkat pemahaman pada suatu objek sumberdaya alam, msisanya apakah jenis sumberdaya alam yang dinilai memiliki pengaruh yang signifikan dalam matapencaharian masyarakat (Daerden et al 2007). Rakhmat (2005) menyatakan persepsi seseorang terhadap suatu objek dipengaruhi oleh faktor utama yaitu faktor personal (fungsional) dan faktor situasional (struktural). Lebih lanjut dijelaskan faktor personal berasal dari kebutuhan, pengalaman masa lalu dan hal-hal lain yang termasuk faktor personal, sedangkan faktor struktural atau situasional adalah semata-mata berasal dari stimulus lingkungan secara fisik. Adapun Perbedaan persepsi masyarakat dapat disebabkan oleh bebera faktor yaitu:

1. Interaksi, interaksi seseorang dengan suatu objek akan memberikan kesan, yang dapat direfleksikan kembali dalam bentuk penilaian dari suatu objek. Dalam hal ini masyarakat yang tinggal di lokasi studi intensitas interaksi dengan lingkungan terjadi secara reguler baik itu pada saat air pasang maupun air surut, sehingga mereka dapat merefleksikan dalam bentuk pengetahuan yang memiliki nilai ekologi.

2. Ketergantungan, nilai ini memiliki makna bahwa masyarakat yang memiliki ketergantungan dalam matapencaharian lebih besar dari keberadaan sumberdaya alam seperti padang lamun akan memberikan penilaian yang lebih tinggi atau kesadaran mereka untuk melakukan perlindungan lamun akan lebih besar dari masyarakat lain yang memiliki tingkat ketergantungan yang lebih rendah dalam memenuhi kebutuhan hidup sehari-hari.

3. Pengetahuan, pengetahuan tidak dapat dibantah perannya bagi setiap orang untuk melakukan penilaian pada suatu objek seperti padang lamun. Pengetahuan dapat diperoleh dari hasil interkasi secara langsung dan pengetahuan yang bersumber dari orang lain yang memiliki pengetahuan yang lebih banyak. Kedua sumber pengetahuan memiliki pengaruh yang signifikan dalam memberikan persepsi sebagai bentuk pengetahuan ekologi masyarakat lokal di lokasi studi.

4. Manfaat, nilai ini lebih pada fungsi dari suatu sumberdaya alam seperti padang lamun dalam hal kegunaanya. Misalnya nelayan kecil yang selalu mencari ikan di sekitar areal padang lamun, tentnu akan memberikan persepsi dan perspketif yang lebih mendalam dalam bentuk pengetahuan ekologi sebagai nilai padang lamun yang harus di lindungi dari ancaman kerusakan.

\section{Perspktif Masyarakat Lokal tentang Perubahan Kondisi Lamun}

Kondisi lamun di lokasi studi dari persepktif masyarakat lokal sebagai responden telah mengalami perubahan, khususnya tentang areal lamun akibat dari perubahan garis pantai dan arah arus yang selalu berubah serta pertumbuhan lamun yang terhambat oleh intensitas pemanfaatan 
yang sangat tinggi oleh masyarakat. Kedua hal tersebut adalah bentuk pengetahuan ekologi masyarakat lokal yang bersumber dari perubahan fisik habitat lamun dan terganggunya pertumbuhan lamun akibat pemanfaatan yang merusak argan pertumbuhan lamun. Selain evaluasi tentang kondisi fisik lamun responden juga diberikan pertanyaan tentang kondisi biota laut yang umum diperoleh dari lokasi padang lamun seperti ikan, moluska, tripang dan beberapa biota laut yang bernilai ekonomi. Dalam hal ini semua responden menyatakan bahwa saat ini sudah sangat kurang jika dibandingkan dengan zaman dulu ( \pm 25 tahun yang lalu).

Dua bentuk pengetahuan ekologi masyarakat lokal yaitu perubahan habitat lamun dan kondisi biota laut yang hidup pada padang lamun dapat menjadi instrumen dalam menilai perubahan kondisi lamun dari ancaman kerusakan baik yang disebabkan oleh perubahan garis pantai dan aktivitas pemanfaatan oleh masyarakat. Pengetahuan ekologi masyarakat lokal dapat sebagai alt untuk mendeteksi perubahan nilai sumberdaya alam dalam jangka waktu panjang yang meliputi luas maupun berkurangnya luas distribusi dari suatu sumberdaya alam (Matthew Lauer dan and Shankar Aswani 2010).

\section{Kesimpulan}

Pengetahuan ekologi masyarakat lokal dapat meliputi pengetahuan masyarakat lokal tentang jenis dan distribusi jenis lamun di lingkungan laut serta manfaat lamun bagi lingkungan laut, khususnya bagi keragaman biota laut yang membutuhkan lamun sebagai habitat. Selain itu pengetahuan ekologi masyarakat lokal dapat dilihat dari pemahaman masyarakat tentang fungsi ekologi lamun sebagai sumber makanan biota laut seperti ikan dan see-urchin serta lamun berperan penting sebagai tempat pemeliharaan ikan-ikan kecil. Masyarakat lokal yang secara reguler berinteraksi dengan sumberdaya alam seperti padang lamun memiliki nilai yang sangat penting untuk mendeteksi perubahan kondisi padang lamun dalam jangka waktu yang cukup lama.

\section{DAFTAR PUSTAKA}

Aswani S, Lauer M. 2006. Incorporating fishers' local knowledge and behavior into geographical information systems (GIS) for designing marine protected areas in Oceania. Human Organization. 65:80-101.

Berkes F, Colding J, Folke C. 2000. Rediscovery of traditional ecological knowledge as adaptive management. Ecological Applications. 10:12511262.

Björk M., Short F., Mcleod, E. and Beer, S.. 2008. Managing Seagrasses for Resilience to Climate Change. IUCN, Gland dan Switzerland. 56.

Cullen L C dan Unsworth R. KF. 2010. Recognising the necessity for IndoPacific seagrass conservation. MiniReview. Conservation Letter. 1 - 11 .

Dearden P, Ellen H, Kanjana AY dan Dave D. 2005. Community perspectives and conservation needs for Dugongs (Dugong-dugong) along the Andaman Coast of Thailand. Environmental Management 36 (5): 654 - 664.

Departemen Kelautan dan Perikanan. 2008. Konservasi Surnberdaya Ikan Di Indonesia: Derektorat Jenderal Kelautan Pesisir dan Pulau-Pulau Kecil, Derektorat Konservasi dan Taman Nasional Laut kerjasama dengan Jepan International Cooperation Agency. 1 - 40. 
Dietz T, Ostrom E, Stern PC. 2003. The struggle to govern the commons. Science. 302:1907-1912.

Duarte CM, Dennison WC, Orth RJW, Carruthers TJB. 2008. The charisma of coastal ecosystems: addressing the imbalance. Estuaries and Coasts. 31:233-238.

Duarte CM, Gattuso J-P. 2008. Seagrass meadows. In: Cleveland $\mathrm{CJ}$, editor. Encyclopedia of earth, environmental information coalition. Washington, DC: National Council for Science and the Environment.

Few R. 2009. Conservation, participation, and power: protected-area planning in the coastal zone of belize. Journal of Planning Education and Research. 19: $410-408$.

Hughes TP, Bellwood DR, Folke C, Steneck RS, Wilson J. 2005. New paradigms for supporting the resilience of marine ecosystems. Trends in Ecology \& Evolution. 20:380-386.

Larkum AWD. Robert JO dan Carlos M. Duarte. 2006. Seagrasses: Biology, Ecology and Conservation. Springer. Netherlands.

Lauer M dan Aswani S. 2008. Integrating indigenous ecological knowledge and multi-spectral image classification for marine habitat mapping in Oceania. Ocean and Coastal Management. 51:495-504.

Lauer M dan Aswani S. 2009. Indigenous ecological knowledge as situated practices: understanding fishers' knowledge in the western Solomon Islands. American Anthropologist. 111:317-329.
Lauer M dan Aswani S. 2010. Indigenous Knowledge and Long-term Ecological Change: Detection, Interpretation, and Responses to Changing Ecological Conditions in Pacific Island Communities. Environmental Management. 45(5): 985-997.

Orth RJ, Carruthers TJB, Dennison WC, Duarte CM, Fourqurean JW, Heck KL, Hughes AR, Kendrick GA, Kenworthy WJ, Olyarnik S, Short FT, Waycott M, Williams SL. 2006. A global crisis for seagrass ecosystems. BioScience. Vol 56: 987-996.

Short FT, Wyllei-Echeverria S. 1996. Natural and human-induced disturbance of seagrasses. Environmental Conservation , Vol 23:17-27.

Short F, Carruthers T, Dennison W, Waycott M. 2007. Global seagrass distribution and diversity: a bioregional model. Journal of Experimental Marine Biology and Ecology. 350: 3-20.

Syukur A, Yusli W, Ismudi M dan Mukhlis K. 2011. Keragaman Jenis lamun dan Kondisinya di Perairan Tanjung Luar Lombok Timur. Biotrofis. Vol 2: 5060.

Syukur A, Yusli W, Ismudi M dan Mukhlis K. 2012. Keanekaragaman Jenis Ikan Pada Padang Lamun di Perairan Tanjung Luar Lombok Timur. Vol 1: $1-12$.

Tomascik TAJ. Mah, A Nontji dan Moosa MK. 1997. The Ecology of the Indonesien seas. P. In the Republic of Singapore. 
Turner S and Anne-Maree Schwarz. 2006. Management and conservation of seagrass in New Zealand: an introduction. Science \& Technical Publishing Department of Conservation PO Box 10-420 Wellington, New Zealand

Ronnback P dan Torre-Castro M. de la. 2004. Links between humans and seagrasses-

Vol. 7 (5). 242 -246. an example from tropical East Africa. Ocean \& Coastal Management 47: 361 $-387$.

Waycott M, Hubes A R, Williams S L, Duarte C M dan Jr Heck K L. 2009. Assosiations of Concern: Declining Seagrass and Threatened Dependent Spesies. Fornt Ecol Environmental. 